\title{
MANTLE STRUCTURE BENEATH UDACHNAYA PIPE RECONSTRUCTED BY FRESH MANTLE XENOLITHS FROM BROWN BRECCIA
}

\author{
Ashchepkov I.V. ${ }^{1}$, Ntaflos T. ${ }^{2}$, Pokhilenko L.N. ${ }^{1}$, Ionov D.A. ${ }^{3}$, Vladykin N.V. ${ }^{4}$, Kuligin S.S. ${ }^{1}$, \\ Mityukhin S.I. ${ }^{5}$, Palessky S.V. ${ }^{\text {a }}$ \\ 1. Institute of Geology and Mineralogy, SD RAS, Novosibirsk, Russia \\ 2. University of Vienna, Austria, 3.Université Lylle, Saint-Etienne, France \\ 4.Institute of Geochemistry SD RAS, Irkutsk, Russia, 5. Stock Company "ALROSA”, Mirny, Russia
}

\section{DATAAND METHODS.}

Minerals from $>340400$ new fresh xenoliths from Udachnaya pipe brown breccias containing absolutely fresh xenoliths (Kamenetsky et al.,2009; Ionov et al., 2011) were analyzed for major and trace elements. EPMA data for minerals from 110 relatively small peridotite- pyroxenite samples $(3-7 \mathrm{~cm})$ were analysed in University of Vienna using Cameca 100SX. Tee high precision analyses of olivines were obtained for 64 associations. The other xenoliths were analysed in IGM, Novosibirsk in mounts and analyses of 27 samples from the same collection were added (Ionov et al., 2011). In addition the published data by (Jagoutz, 1973; Jacob et al., 1974; Snyder et al., 1997; Pokhilenko et al., 1976- 2000; Griffin et al., Boyd et al., 1997; Smith, 1999; Kuligin et al., 1995; Malygina et al., 2000; Pokhilenko et al., 2006; Shatsky et al., 2008; Ionov et al., 2010 etc) including $\sim 1800$ associations and xenocrysts were used for the deciphering of the mantle structure and layering starting at depth of $80 \mathrm{kbar}$.

\section{MINERALOGY OF XENOCRYSTS}

GARNETS show high variations in $\mathrm{Cr}_{2} \mathrm{O}_{3}$ within lherzolite field (Sobolev et al., 1973). Green garnets form wehrlites have the higest $\mathrm{Cr}_{2} \mathrm{O}_{3}$ and $\mathrm{CaO}$ contents (13.8 and 8.0-9.0 wt\% respectively (Fig.1). Rare dunites and harzburgites reveal sub calsic garnet compositions such as in diamond inclusions (Logvinova et all .,2005; Sobolev et al.,1987 ). The garnets from $\mathrm{Phl}$ bearing associations often show mainly enrichment in $\mathrm{TiO}_{2}$ indicating that .

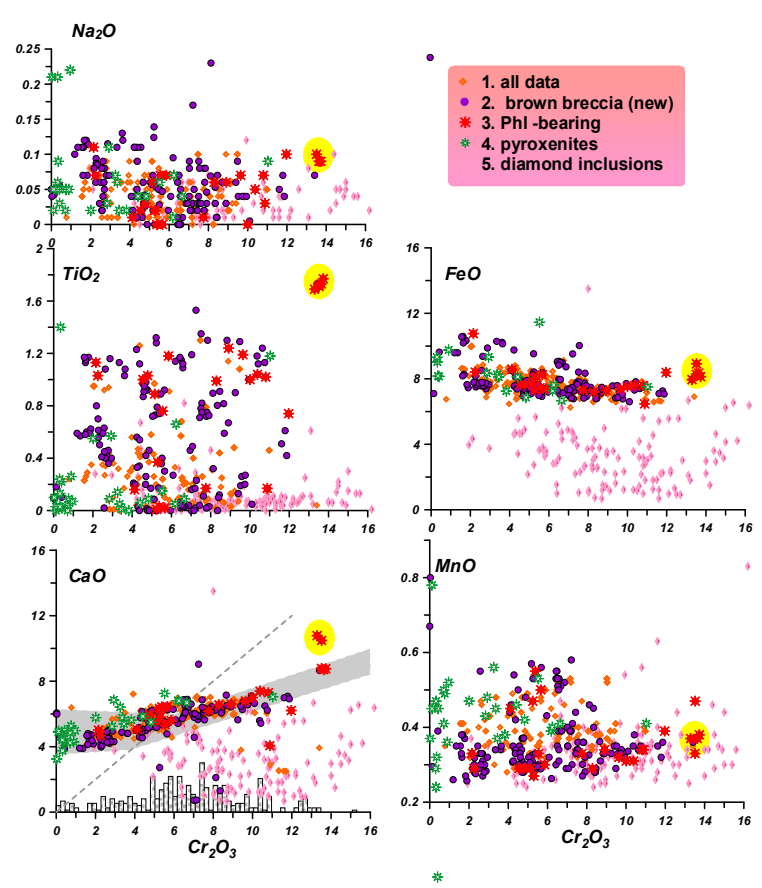

Fig.1. Variations of major element compositions of the garnets from brown kimberlite breccia in comparison with other published data from Udachnaya pipe. 1. Published previous data. 2.new data. 3. $\mathrm{Phl}$ bearing associations. 4 . Pyroxenites, wehrlite is marked by circle 
CR-DIOPSIDES form brown breccia peridotite xenoliths (Fig.2). repeat variations of previous collections but are higher in $\mathrm{TiO}_{2}$ and $\mathrm{Cr}_{2} \mathrm{O}_{3}$.

CHROMITES show variations from 10 to $60 \% \mathrm{Cr}_{2} \mathrm{O}_{3}$, the varieties $>40 \mathrm{Cr}_{2} \mathrm{O}_{3}$ are enriched in $\mathrm{TiO}_{2}$ and $\mathrm{FeO}$ which is more typical for the pyroxenites and phlogopites (Fig.3) when compared to the published data.

ILMENITES found in carbonite - bearing phlogopie- bearing veins $7-11 \mathrm{Wt} \% \mathrm{MgO}$ in peridotites and Cr-low pyroxenites (Alymova et al., 2004) are close in compositions to the xenocrysts in kimberlites

PHLOGOPITES The compositions of the phlogopites are ranging in $\mathrm{FeO}$ from 2 to $6.5 \%$ (Fig. 4) whereas $\mathrm{FeO}$ in $\mathrm{Phl}$ from olivine $-\mathrm{Phl}$ breccia ranges from 5 to $8.5 \%$, they are low in $\mathrm{Cr}_{2} \mathrm{O}_{3}$ but higher in $\mathrm{Na}_{2} \mathrm{O}$ (to $1.5 \%$ ).

\section{HIGH PRECISION DATA FOR OLIVINE}

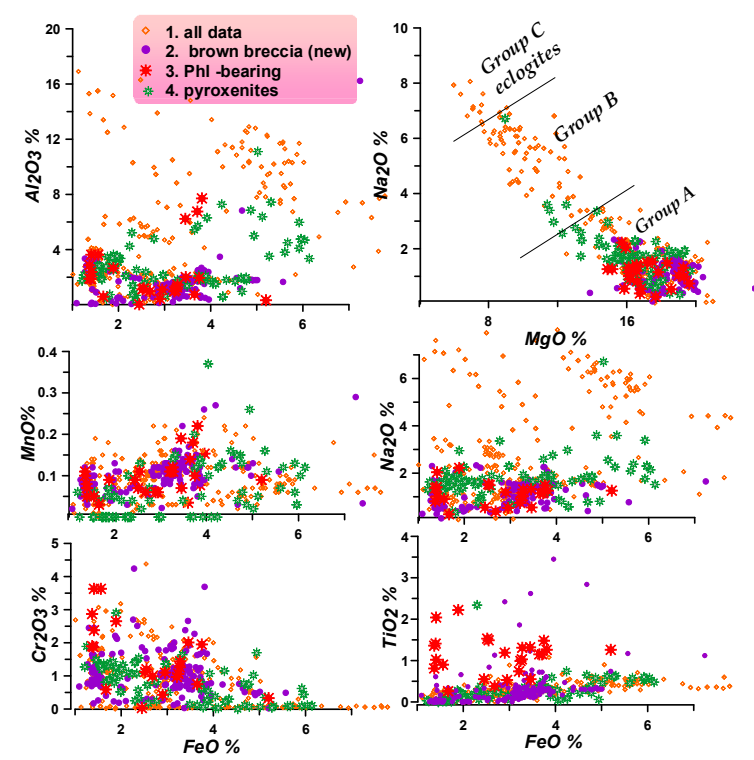

Fig.2. Variations of major element compositions from the clinopyroxenes of brown kimberlite breccia in comparison with other published data from Udachnaya pipe, Eclogite groups after (Dawson, 1980).

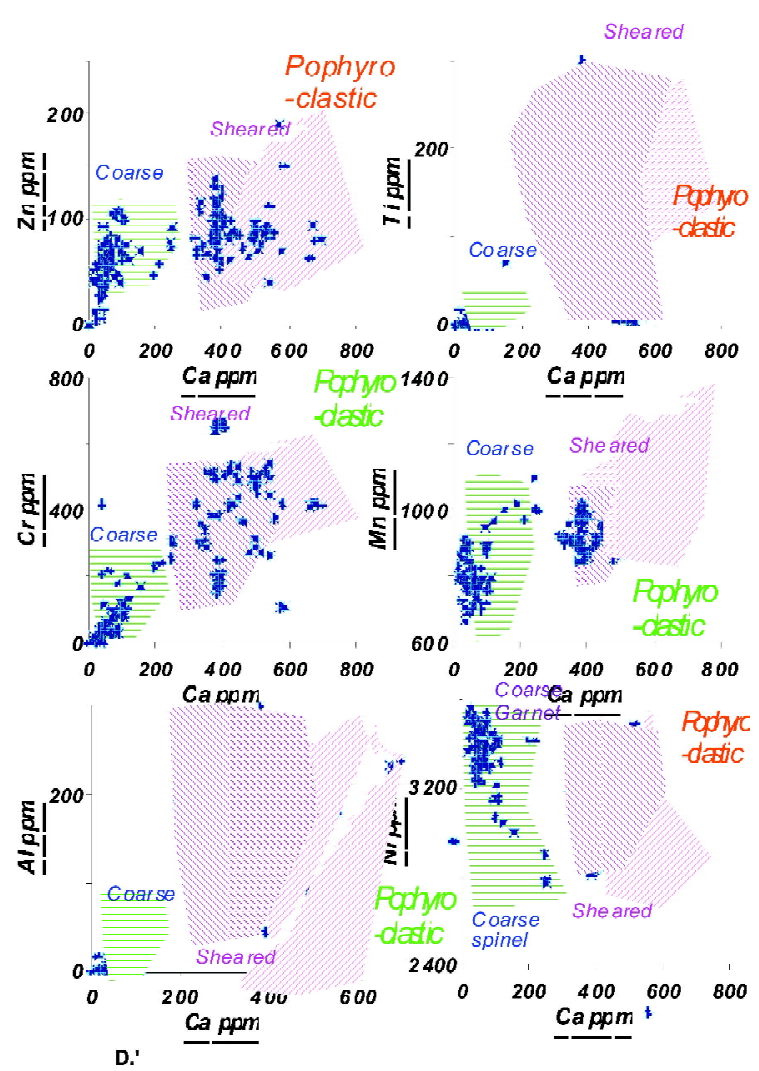

Fig.5. Minor element variations in olivine obtained with the high precision olivine measurements.

The high precision olivine trace element microprobe analyses (HPA) for 64 xenoliths obtained using CAMECA100SX are divided into 3 major groups. Group 1 consisting of porphyroclastc and/or shared peridotites is characterized by high $\mathrm{Ca}$, Ti. Group 2 consists of coarse grained garnet peridotites that have low $\mathrm{Ca}-$ and high Ni- olivines. Group 3 are low pressure garnet-spinel peridotites with low Niolivines.

\section{THERMOBAROMETRY OF OLIVINE}

The Al- and Cr-in-olivine thermometer (De Hoog et al., 2010) provides temperatures comparable to those calculated using orthopyroxene thermometry (Fig. 6b) (De Hoog et al., 2010) especially based on $\mathrm{Cr}-\mathrm{Al}$ exchange 


\section{0 $^{\text {th }}$ International Kimberlite Conference, Bangalore - 2012}

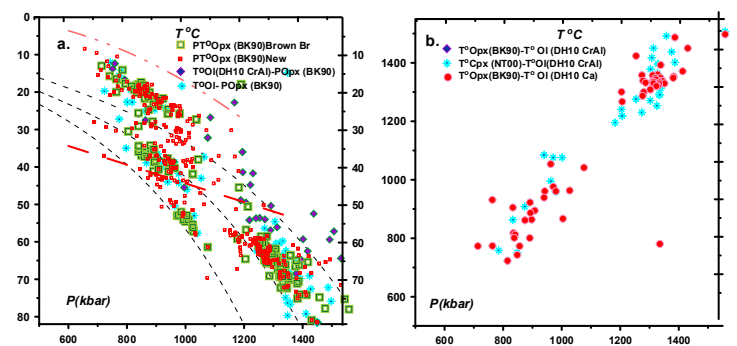

Fig.6. PT conditions for peridotites from the brown kimberlite breccia, ,Udachnaya pipe (new data). a. PT Correlations of the $\mathrm{Ol}-$ based $\mathrm{T}$ and Px- based pressure. Symbols like in Fig. 7. b: Temperatures calculated using Ol-thermometry are similar to those calculated using Px thermometry.

provide results very similar to pyroxene temperatures. (Fig6. b). Using this thermometry and common Opx barometry the obtain geotherm is nearly the same like as constructed by most effective methods (Brey, Kohler, 1990). De Hoog and colleagues (2010) reported that these thermometric equations in inverse form may be used as barometers. Nevertheless in general they give lower pressures then Opx based method (Brey, Kohler, 1990). Ca-Ol-Cpx barometry for olivine (Kohler, Brey, 1990) also give not regular geotherms when using this equation together with the Ol thermometers. The modification of inversed (De Hoog et al., 2010) equations with the corrections for $\mathrm{Mn}, \mathrm{Al}, \mathrm{Cr}$ and Ti HPA is promising for the good barometric method.

\section{THERMOBAROMETRYAND RECONSTRUCTIONS OF MANTLE SECTION.}

The Udachnaya SCLM section (Pokhilenko et al., 2000æ Ashchepkov et al., 2003): 1. The layer (75-60kbar) includes sheared and porhyroclastic peridotites, dunite veins with the $\mathrm{Chr}$, Gar and Ilm and Ilm metasomatites; 2 . The layer (60- $55 \mathrm{kbar}$ ) - eclogites lens and low -T dunites; 3. (55-45 kbar) low- $\mathrm{T}^{\circ}$ lower layered ultramafic unit 4. (45-40 kbar) pyroxenite lens; 5. (40-30 kbar) low- $\mathrm{T}^{\mathrm{o}}$ upper garnet peridotite unit. 6. (30-10 kbar) high $\mathrm{T}^{\circ}$ and low-T Sp- Gar and $\mathrm{Sp}$ lherzolites and $\mathrm{Fe}$ - rich pyroxenites.
Measurements in thin sections of small xenoliths which are commonly represent the disintegrated material close to the melt channels gave more points tracing advective branch from 80 to 40 kbars. Most of them refer to the porphyroclastic or shared peridotites of polybaric nature (Katayama et al., 2009). Colder associations $33 \mathrm{mw} / \mathrm{m}^{2}$ occurs at least in three intervals from the base of SCLM.

New data for phlogopite bearing associations show that the metasomatism refer to lowermost part of SCLM to pyroxenite layer and to the incline PT path joining the advective PT path which is traced by the PT for secondary $\mathrm{Cr}-$ diopsides rising from base to pyroxenite layer. The $\mathrm{P}-\mathrm{Fe}$ \# diagram for the

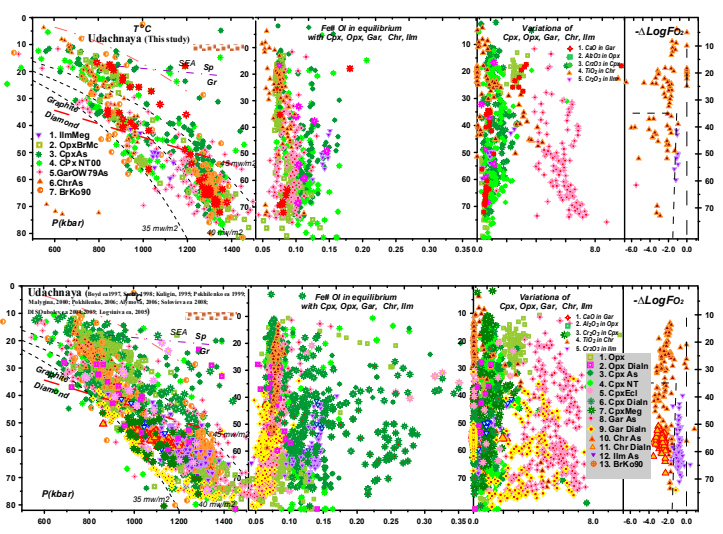

Fig.7. $\mathrm{PTXFO}_{2}$. PT conditions for only new data for brown breccia B PT conditions for the new data for all previous data set of deep seated inclusions from Udachnaya pipe. Signs see legend, methods: (Ashchepkov et al., 2010). NT- (Nimis, Taylor, 2000). BrKo- Brey, Kohler, 1990.

\section{THE DEEP PHLOPITE-OLIVINE BRECCIAS}

Two kinds of the deep essentially Phl-Ol magmatic breccias were found: 1) Ol-Phl-Ilm aggregates containing abundant xenocrysts of $\mathrm{Ol}$ (7-14\% FeO), picroilmenites (6-14\% MgO). 2) Ol-Phl-Chr aggregates, where intergranular minerals: Ti-Fe, Cpx, richterite Amph, Ti- Phl and $\mathrm{K}$-fieldspar evidences that final crystallization probably took place near Moho boundary. But 


\section{0 $^{\text {th }}$ International Kimberlite Conference, Bangalore - 2012}

original material includes fragments of very deep sheared peridotites. All garnet and pyroxenes were dissolved. Abundant Ol- Chr aggregates varying in compositions with wide range of compositions with increasing $\mathrm{Fe}, \mathrm{Al}$, $\mathrm{Ti}$ in $\mathrm{Chr}$.

Breccies reflect crystallization of two types of deep seated hydrous protokimberlite which coursed the Phl metasomatism in mantle from base to the SCLM top in vicinity of the magma feeders.

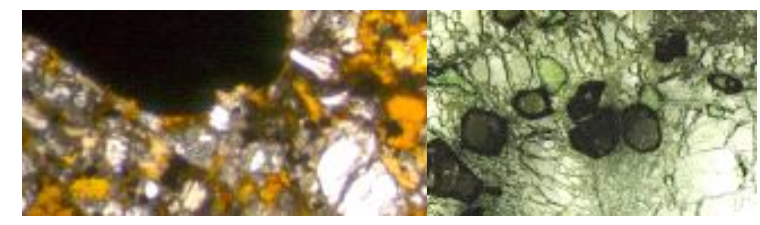

Fig. 8. a) $\mathrm{Phl}-\mathrm{Ilm}-\mathrm{Chr}$ magmatic breccia from Udachnaya pipe; b) xenolith of wehrlite with green garnet $\left(14 \% \mathrm{Cr}_{2} \mathrm{O}_{3}\right)$

\section{GEOCHEMISTRY}

Garnet and clinopyroxene chondritenormalized trace element abundances from eclogites, garnet- peridotites and pyroxenites are shown in Fig.9 Both, garnet and clinopyroxene TRE- patterns reveal the depleted character of the studied associations. Sigmoidal garnet REE patterns with lower TRE content for peridotitic garnets, indicating metasomatic events (Fig. 9a) are common for sub-Ca compositions. All patters show deep $\mathrm{Sr}, \mathrm{Ba}$, Th minima and $\mathrm{Zr}$ and Hf dips, elevated $\mathrm{U}$ and $\mathrm{Nb}$ and $\mathrm{Ta}$ (Fig.9). Pyroxenitic garnets show mainly rounded patterns and higher peaks in $\mathrm{Nb}$ and $\mathrm{Ta}$. Eclogitic garnets of subductions type are low in TRE level and display jugged spiderdiagram while melt metasomatized reveal smooth patters and high TRE level. The trace elements patterns for the Cpx from the deep seated xenoliths demonstrate highly inclined patterns with the small hump which is shifted to the left part of the REE patterns (Fig.9). The TRE are complex and varying. Clinopyroxenes from peridotites show highly inclined $(\mathrm{Ga} / \mathrm{Yb})_{\mathrm{n}}$ REE patterns $(<1 \%$ melting and high $\mathrm{Ga} / \mathrm{CPx})$. The TRE are varying from fertilized close to derived from protokimberlites (Kamenetsky et al., 2009)

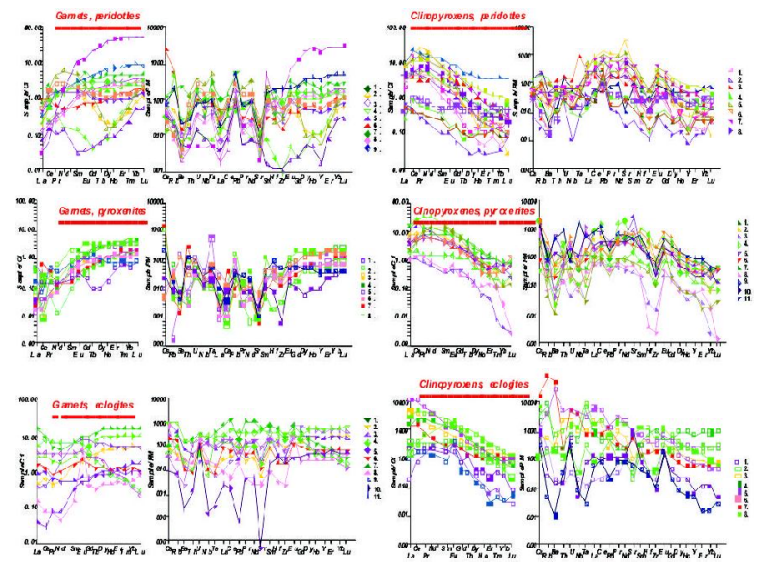

Fig. 9. Trace element patterns for minerals from deep-seated inclusions Udachnaya pipe

like those from $\mathrm{Cr}$ - Ti rich green garnets to nearly primitive for $\mathrm{Cpx}$ - rich from sheared varieties (Agashev et al., 2010). In depleted peridotites from upper part of SCLM the inclinations of REE and TRE patterns are varying.

The LREE enriched harzburgites related to the fluid-rich melt interactions are intercalated with LREE depleted varieties. Cpx REE patterns from pyroxenites are nearly uniform $(\sim 1 \%$ melting). Eclogite's Cpx highly differ. The TRE level is lower for those with the signs of the primary subduction origin showing $\mathrm{Eu}, \mathrm{U}, \mathrm{Sr}$ peaks. Those refered to the metasomatic or remelted type (Misra et al., 2004;

Shatsky et al., 2008) show higher TRE level and midly inclined REE patterns, TRE fluctuation in $\mathrm{Ta}$ and elevated LILE are marking protokimberlite metasomatism.

The TRE patterns for the phlogopites reveal high inclination in general. The TRE are jugged with the picks in LILE components and $\mathrm{Sr}, \mathrm{Pb}$ and depression in Th and some HFSE.

\section{DISCUSSION}

The detail thermobarometry show that there are high variations of the PT conditions referred to the different lithosphere thickness (Artemieva et al., 2009). 


\section{0 $^{\text {th }}$ International Kimberlite Conference, Bangalore - 2012}

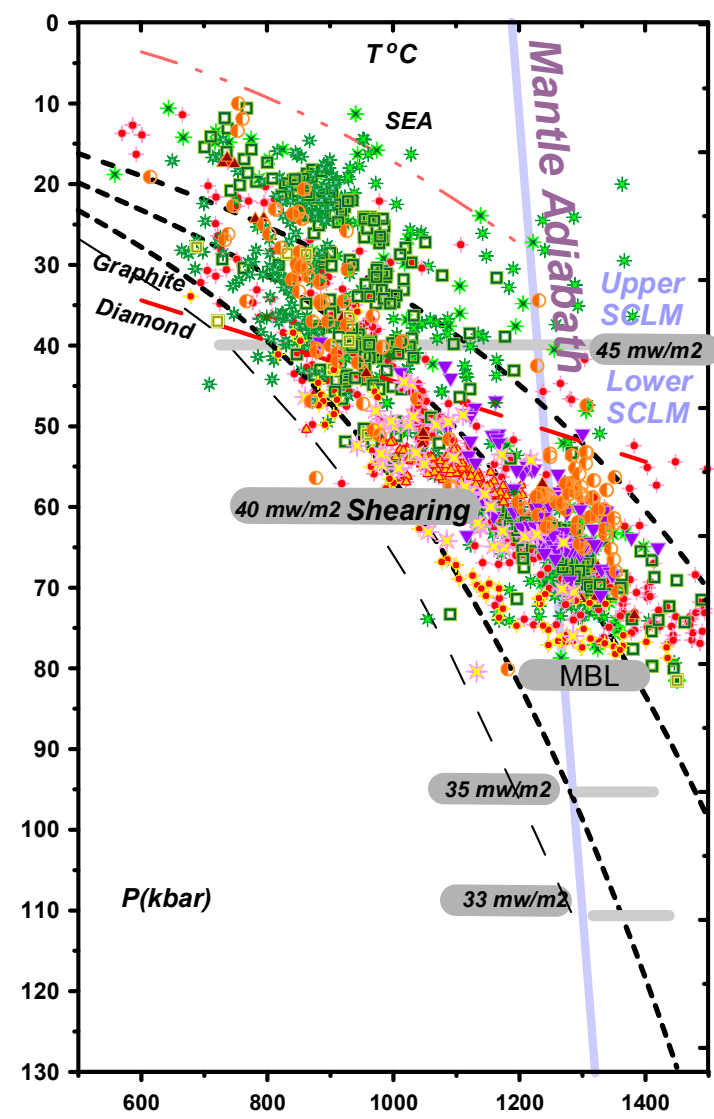

Fig.10. Variations of the geothermal regime according to the decreasing of the lithosphere thickness.

Wide variations of the mineral compositions and position of the geotherms from the SCLM base to $20 \mathrm{kbars}$ show that interactions in several (6) levels of SCLM took place under the influence of 3 major stages of plume melts intrusions including protokimberlites. The deeper level was undergone to the influence of the protokimberlite melts which created magmatic chamber or melt feeder and - vein system within 75 and 55 kabrs created major portion of megacrysts and coursed the deformations of the peridotites due to hydraulic fracturing, submelting and high scale interactions. Existence of relatively easy melted material like eclogites and melt conduits like dunites in SCLM base were probably responsible for the melt concentration and diamond growths.
The upper $55-40 \mathrm{kbar}$ levels is correspondent mainly to the interactions around the veins which should be formed by the moving of protokimberlites which became essentially carbonatitic in the level near the middle part of SCLM due to the splitting of the primary melts during the differentiation, rising and cooling. Such systems containing abundant carbonates are favorable for the creation of the diamonds (Zedgenizov et al., 2004; Rege et al., 2009) as a result of interactions with the reduced peridotites (Logvinova, Ashchepkov, 2008). Stopping of the pervasive melt percolation pobably occurred near $40 \mathrm{kbar}$ hear the layer of pyroxenites and eclogites.

The large unites in the mantle columns were created by subduction processes and most Fe-rich eclogites should correspond to the upper parts of the subduction slabs.

The layer of the garnet dunites (Pokhilenko et al., 1991) beneath at the SCLM base was created in Archean time probably by subduction related fluids and wad later used by the kimberlite magmas for the melt transfer.

The thermal boundary layer (Artemieva et al., 2009) near $65 \mathrm{kbar}$ corresponds to the temperature minima of the oxidized peridotite solidus at SCLM base (Tappe et al., 2007) due to interaction with lower eclogitic lens. The heterogeneity of the base and abundance of dunites served as melt transfers were responsible for the high degree interaction in 80-50 kbar interval. The chemical boundary for carbonated peridotites near $40 \mathrm{kbars}$ should bring to the melt concentration and creation of the pyroxenite lens. The separate high temperature level appeared in the upper part near the Gar-Sp boundarywere melts werew concentrated also. The 20-30 kbar trap for hydrous melts was responsible was abundant melt percolation on this interval. Possibly most evolved $\mathrm{H}_{2} \mathrm{O}$ rich protokimberlite melt portion reached this level as it seen from Ol$\mathrm{Phl}$ breccia. But it also likely that heating within the Sp-Gar facie was close the stage before kimberlites when basalt abundant in this area and 


\section{0 $^{\text {th }}$ International Kimberlite Conference, Bangalore - 2012}

as the xenoliths in kimberlites were erupted. Grant RBRF 05-11-00060à 11-05-91060-PICSa

\section{References}

Agashev, A.M., Pokhilenko, N.P., Cherepanova, Yu.V, Golovin, A.V. 2010. Geochemical evolution of the rocks of the mantle lithosphere base according to study of the xenoliths of sheared peridotites from the kimberlites from Udachnaya pipe. Doklady RAS ESS 432. 510-513.

Alymova, N.A., Kostrovitsky, S. I., Ivanov, A.S., Serov, V. P. 2004. Picroilmenites from kimberlites of Daldyn field, Yakutia. Doklady of Russian Academy of Sciences Earth Science Sections, 395, 444-447.

Artemieva, I. M. 2009. The continental lithosphere: Reconciling thermal, seismic, and petrologic data. Lithos, 109, 23-46

Ashchepkov, I.V., Pokhilenko, N.P., Vladykin, N.V., Logvinova, A.M., Kostrovitsky, S.I., Afanasiev, V.P., Pokhilenko, L.N., , Kuligin, S.S., Malygina, L.V., Alymova, N.V., Khmelnikova, O.S., Palessky, S.V., Nikolaeva, I.V., Karpenko, M.A., Stagnitsky, Y.B. 2010. Structure and evolution of the lithospheric mantle beneath Siberian craton, thermobarometric study. Tectonophysics. 485, 17 41.

Brey, G.P., Kohler, T. 1990. Geothermobarometry in four-phase lherzolites. II. New thermo-barometers, and practical assessment of existing thermobarometers. Journal of Petrology, 31, 13531378.

Boyd F.R., Pokhilenko N.P., Pearson D.G., Mertzman S.A., Sobolev N.V., Finger L.W. 1997. Composition of the Siberian cratonic mantle: evidence from Udachnaya peridotite xenoliths. Contrib. Mineral. Petrol, 128, 228-246.

Dawson J.B. 1980. Kimberlites and their xenoliths. Springer-Verlag, Berlin Heidelberg New York.

De Hoog J.C.M., Gall G., Cornell D.H. 2010. Traceelement geochemistry of mantle olivine and application to mantle petrogenesis and geothermobarometry. Chemical Geology. 270, 196215.

Griffin W.L., Ryan C.G., Kaminsky F.V., O'Reilly S.Y., Natapov L.M., Win T.T., Kinny P.D., Ilupin I.P. 1999. The Siberian lithosphere traverse: Mantle terranes and the assembly of the Siberian Craton. Tectonophysics, 310, 1-35.

Griffin W.L., Sobolev N.V., Ryan C.G., Pokhilenko N.P., Win T.T., Yefimova E.S. 1993. Trace elements in garnets and chromites: diamond formation in the Siberian lithosphere. Lithos 29, 235-256

Ionov D.A., Doucet L.S., Ashchepkov. I.V. 2011. Composition of the Lithospheric Mantle in the Siberian Craton: New Constraints from Fresh Peridotites in the Udachnaya-East Kimberlite. J. Petrology.

Jacob, D., Jagoutz, E., Lowry, D., Mattey, D., Kudrjavtseva, G. 1994. Diamondiferous eclogites from Siberia: remnants of Archean oceanic crust. Geochim. Cosmochim. Acta 58, 5191-5207.

Jagoutz E., Lowry D., Mattey D., Kudrjavtseva G. 1993. Diamondiferous eclogites from Siberia: Remnants of Archean oceanic crust. .Geochim. Cosmochim. Acta.58,.5195-5207

Kamenetsky V.S, Kamenetsky M.B., Sobolev A.V., Golovin A.V., Sharygin V.V., Pokhilenko N. P., Sobolev N.V. 2009. Can pyroxenes be liquidus minerals in the kimberlite magma? Lithos, 112, S1, 213-222

Katayama I., Suyama Y., Ando S., Komiya T. 2009. Mineral chemistry and $\mathrm{P}-\mathrm{T}$ condition of granular and sheared peridotite xenoliths from Kimberley, South Africa: Origin of the textural variation in the cratonic mantle. Lithos. 109 (3), 333-340.

Kawamoto, T., Herig, R.L., Holloway, J.R. 1996. Experimental evidence for a hydrous transition zone in the early Earth's mantle. Earth Planet. Sci. Lett. 142, 587-592.

Kohler T., Brey G.P. 1990. Calcium exchange between olivine and clinopyroxene calibrated as a geothermobarometer for natural peridotites from 2 to $60 \mathrm{~kb}$ with applications. Geochim Cosmochim Acta 54, 23752388

Kuligin S.S. 1997. Complex of pyroxenite xenoliths in kimberlites from different regions of Siberian platform. PhD thesis, United Institute of Geology Geophysics and Mineralogy, Novosibirsk. 220p..

Kuligin S.S., Malkovets V.G., Pokhilenko, N.P., Vavilov M.A., Griffin W.L., O'Reilly S.Y. 2003. Mineralogical and Geochemical Characteristics of a Unique Mantle Xenolith from the Udachnaya Kimberlite Pipe. Extended Abstracts of 8 International Kimberlite Conference. FLA_0114. 


\section{0 $^{\text {th }}$ International Kimberlite Conference, Bangalore - 2012}

Kuligin S.S., Pokhilenko N.P. 1998. Mineralogy of xenoliths of garnet pyroxenites from kimberlite pipes of Siberian platform . Extended Abstracts 7IKC. Cape Town. Đ. 480- 482.

Logvinova A.M. Taylor L.A. Floss C. Sobolev N.V. 2005. Geochemistry of multiple diamond inclusions of harzburgitic garnets as examined insitu International Geology Review. 47, 1223-1233

Logvinova, A.M., Ashchepkov, I.V. 2008. Diamond inclusions and eclogites thermobarometry, Siberia. Goldschmidt Conference Abstracts Geochimica et Cosmochimica Acta. Special Supplement. 72. 16S, A567

Malygina, E.V. 2000. Xenoliths of granular mantle peridotites in Udachnaya pipe. $\mathrm{PhD}$ thesis, United Institute of Geology Geophysics \& Mineralogy, Novosibirsk. 187 p.

MacGregor I.D. 1974 The system MgO-Al2O3-SiO2: solubility of A12O3 in enstatite for spinel and garnet peridotite compositions. Am Mineral. 59, 110-119

Misra K.C., Anand M.; Taylor L.A., Sobolev N.V. 2004. Multi-stage metasomatism of diamondiferous eclogite xenoliths from the Udachnaya kimberlite pipe, Yakutia, Siberia . Contrib Mineral Petrol. 146, 696-714.

Nimis, P. Taylor, W. 2000. Single clinopyroxene thermobarometry for garnet peridotites. Part I. Calibration and testing of a Cr-in-Cpx barometer and an enstatite-in-Cpx thermometer. Contrib. Mineral. Petrol., 139, 541-554.

Nimis P, Zanetti A, Dencker D., Sobolev N.V. 2009. Major and trace element composition of chromian diopsides from the Zagadochnaya kimberlite (Yakutia, Russia): metasomatic processes, thermobarometry and diamond potential. Lithos $112(3-4), 397-412$.

Pearson, D.G. The age of continental roots, 1999. Lithos, 48, 171-194.

Pokhilenko N.P., Boyd F.R., Ashchepkov I.V., Kuligin S.S., Malygina E.V. 2000. Layered mantle beneath Udachnaya pipe: OPX thermobarometry. Geophysical Research Abstracts, 2, 154.

Pokhilenko, L.N., 2006. Volatile composition and oxidation state of mantle xenoliths from Siberian kimberlites. / PhD thesis, United Institute of Geology Geophysics and Mineralogy, Novosibirsk. $225 \mathrm{p}$.

Pokhilenko, N. P., Pearson, D. G., Boyd, F. R., Sobolev,
N.V. 1991. Megacrystalline dunites: sources of Siberian diamonds. /Carnegie Inst. Washington Yearbook, 11-18.

Pokhilenko, N. P., Sobolev, N.V., Kuligin, S. S., Shimizu, N., 1999. Peculiarities of distribution of pyroxenite paragenesis garnets in Yakutian kimberlites and some aspects of the evolution of the Siberian craton lithospheric mantle.// Proceedings of the VII International Kim-berlite Conference. The P.H. Nixon volume. P. 690-707

Pokhilenko, N.P., Sobolev, N.V., Sobolev, V.S., Lavrentiev, Yu.G. 1976. Xenolith of diamond bearing ilmenite-pyrope lherzolite from the Udachnaya kimberlite pipe, Yakutia. Doklady AN SSSR, 231, 149-151.

Shatsky V., Ragozin A., Zedgenizov D., Mityukhin S., 2008. Evidence for multistage evolution in a xenolith of diamond-bearing eclogite from the Udachnaya kimberlite pipe. Lithos 105, 289-300.

Rege S., Griffin W.L., Pearson N.J., Araujo D., Zedgenizov D., O'Reilly S.Y. 2010. Trace-element patterns of fibrous and monocrystalline diamonds: Insights into mantle fluids. Lithos, 118, 13-337

Snyder, G.A., Taylor, L.A., Crozaz, G., Halliday, A.N., Beard, B.L., Sobolev, V.N., 1997. The Origins of Yakunan Eclogite Xenoliths. J. Petrol., 38, 85-113. Sobolev N.V., Lavrent'ev Yu.G., Pokhilenko N.P., Usova L.V. 1973. Chrome-rich garnets from the kimberlites of Yakuti and their parageneses. Contrib Mineral Petrol., 40, 39-52.

Sobolev N.V., Logvinova A.M., Zedgenizov D.A., Pokhilenko N.P., Malygina E.V., Kuzmin D.V., Sobolev A.V. 2009. Petrogenetic significance of minor elements in olivines from diamonds and peridotite xenoliths from kimberlites of Yakutia. Lithos, 112 S1 pp. 701-713

Sobolev V.N., Taylor L.A., Snyder G.A., Sobolev N.V. 1994. Diamondiferous eclogites from the Udachnaya pipe, Yakutia. International Geology Review, 36, 42-64

Sobolev, N V, Logvinova, M, Zedgenizov, D. A, et al.. 2004. Mineral inclusions in microdiamonds and macrodiamonds from kimberlites of Yakutia: a comparative study. Lithos, 77, 225-242.

Sobolev, N. V., Pokhilenko, N. V. \& Efimova, E. S.. Diamond-bearing peridotite xenolihs in kimberlite and the problem of the origin of diamonds. Geologiya i Geofizika. 1984., v.25, pp. 63-80. 


\section{0 $^{\text {th }}$ International Kimberlite Conference, Bangalore - 2012}

Sobolev, N.V., 1977. Deep-Seated Inclusions in Kimberlites and the Problem of the Composition of the Mantle./ Amer. Geophys.Union, Washington, DC. 279 p.

Sobolev N.V., Logvinova A.M., Efimova E.S, 2009. Syngenetic phlogopite inclusions in kimberlitehosted diamonds implications for role of volatiles in diamond formation. Russian Geology and Geophysics .50 1234-1248

Solov'eva, L.V., Lavrent'ev, Yu.G., Egorov, K.N., Kostrovitskii S.I., Korolyuk V.N., Suvorova L.F., 2008. The genetic relationship of the deformed peridotites and garnet megacrysts from kimberlites with asthenospheric melts. Russian Geology and Geophysics.. 49, 207-224.
Tappe, S., Foley, S.F., Jenner, G.A., Heaman L.M., Kjarsgaard B. A., Romer R. L., Stracke A., Joyce N. and Hoefs J. 2006. Genesis of ultramafic lamprophyres and carbonatites at Aillik Bay, Labrador: a consequence of incipient lithospheric thinning. beneath the North Atlantic craton Journal of Petrology 47, 1261-1315.

Zedgenizov, D.A., Kagi, H., Shatsky, V.S., Sobolev N.V,. 2004 Carbonatitic melts in cuboid diamonds from Udachnaya kimberlite pipe (Yakutia): evidence from vibrational spectroscopy. Miner. Magazine v.68, pp.61-73. 